\title{
İnternet Sitesi Tasarımının Müșteri Güveni, Müșteri Memnuniyeti ve Satın Alma Niyetine Etkisi ${ }^{1}$
}

\author{
Kalender Özcan ATILGAN \\ Sorumlu Yazar, Mersin Üniversitesi, Erdemli UTIYO, \\ atilgan@mersin.edu.tr,ORCID: 0000-0003-1482-4505 \\ Hussein ALHUSSEIN \\ Mersin Üniversitesi, Sosyal Bilimler Enstitüsü, İşletme Bilgi Yönetimi ABD, \\ hussein.alhussein.1992@gmail.com,ORCID:0000-0001-8175-9016
}

\begin{abstract}
$\ddot{O}_{z}$
İnternet teknolojisinin işletmecilik uygulamalarında kullanımının yaygınlaşmasıyla e-ticaret alanı genişlemiş, dolayısıyla tüketiciler çevrimiçi alışveriş yapmaya daha fazla yönelmişlerdir. Çevrimiçi alışveriş, tüketiciler için birçok avantaj sağlasa da çevrimiçi alıșverişte satıcılara güven duyulması konusunda sorunlar yaşanabilmektedir. Özellikle çevrimiçi alışverişte satıcı ve müşteri arasında ana arayüz olan internet sitesi tasarımı faktörleri olan bilgi tasarımı, navigasyon tasarımı ve grafik tasarımının, müşteri güveni ve memnuniyeti sağlayarak, tüketicilerin satın alma davranışına dönüşmesinde önemli bir etkisi olduğu bilinmektedir. Bu çalışmanın amacı da çevrimiçi alışverişte internet sitesi tasarımı faktörlerinin, çevrimiçi müşteri güven, memnuniyet ve satın alma niyeti etkisini araştırmaktır. Bu bağlamda, Bursa ilinde eğitim gören 441 üniversite öğrencisine amaçlı örnekleme yöntemiyle ulaşılmış ve uygulanan anketler yoluyla araştırma değişkenlerine yönelik ifadelere katılım düzeyleri ölçülmüştür. Araştırmanın hipotezlerini test etmek amacıyla aşamalı regresyon analizi uygulanmıştır. Araştırmanın analiz sonuçlarına göre, dijital pazarlama ve e-ticaret literatüründe yer alan birçok araştırmayla benzer sonuçlara ulaşılmış olup, internet site tasarımının çevrimiçi müşteri güveni, memnuniyeti ve satın alma niyetini etkilediği ortaya çıkmıştır.
\end{abstract}

Anahtar Kelimeler: E-ticaret, İnternet Sitesi Tasarımı, Müşteri Güveni, Müșteri Memnuniyeti, Satın Alma Niyeti

Jel Sinıflandırma Kodları: M30, L81, M15

The Effect of Website Design on Customer Trust, Customer Satisfaction, and Purchase Intention ${ }^{2}$ Abstract

With the widespread use of internet technology in business applications, the field of e-commerce has expanded, so consumers have more tended to shop online. Although online shopping offers many advantages for consumers, there may be problems to trust sellers. It is known that website design factors (information design, navigation design and visual design), which are the main interface between seller and customer, especially in online shopping, have an important effect on directing consumers to purchasing behavior by providing customer trust and satisfaction. The aim of this study is to investigate the effect of website design factors in online shopping, online customer trust, satisfaction and purchase intention. In this context, 441 university students studying in the province of Bursa were reached with the purposive sampling method and the level of participation in the statements regarding the research variables was measured through the questionnaires applied. Stepwise linear regression analysis was carried out to test the research hypotheses. According to the analysis results of the study, similar results have been reached with many studies in the digital marketing and e-commerce literature, and it has been revealed that the website design have effects on online customer trust, customer satisfaction and purchase intention.

Keywords: E-commerce, Website Design, Customer Trust, Customer Satisfaction, Purchase Intention JEL Classification Codes: M30, L81, M15

\footnotetext{
${ }^{1} \mathrm{Bu}$ makale yazarlardan Hussein ALHUSSEIN'in Mersin Üniversitesi Sosyal Bilimler Enstitüsü'nde Doç. Dr. Kalender Özcan ATILGAN'ın danışmanlığında hazırladığı, 2020 yılında tamamlanan yüksek lisans tezinden üretilmiştir.

${ }^{2}$ Extended abstract is presented at the end of the article.
}

Geliş Tarihi (Received): 23.12.2020 - Kabul Edilme Tarihi (Accepted): 23.05.2021

Atıfta bulunmak için / Cite this paper:

Atılgan, K. Ö. ve Alhussein, H. (2021) İnternet sitesi tasarımının müşteri güveni, müşteri memnuniyeti ve satın alma niyetine etkisi. Çankırı Karatekin Üniversitesi İ̈BF Dergisi, 11 (1), 351-375. Doi: 10.18074/ckuiibfd.840405 . 


\section{Giriş}

İnternete erişimi sağlayan cihazların yaygın kullanımı ve internet erişiminin yaygınlaşması, işletmelerin çağın koşullarına göre rekabet edebilmek ve elektronik pazar paylarını oluşturmak amacıyla dijital pazarlama stratejilerini internet üzerinden gerçekleştirmeye yöneltmiştir. Diğer yandan özellikle 2019 yılında ortaya çıkan Covid-19 pandemisi sonucu, tüketicilerin elektronik perakende kanallarından alışverişe daha fazla uyum sağladıkları ve bu anlamda da e-ticaret hacminde kayda değer bir artış olduğu bilinmektedir (Örneğin, Alaimo, Fiore ve Galati, 2020; Baltacı ve Akaydın, 2020). İşletmelerin, e-ticaret ile birlikte ortaya çıkan bu yeni rekabet ortamında başarılı olabilmeleri, müşterilerini internet sitelerinden alışveriş yapmaya teşvik etmelerine bağlı olmaktadır. İşletmelerin internet sitelerinin tasarımının, müşterilerin çevrimiçi alışverişe yönlendirilmesi bağlamında işletme yöneticilerinin olduğu kadar, araştırmacıların da dikkatini çekmektedir. İşletmeler, kurumsal bir internet sitesi oluşturmak ve sürdürmek için yılda milyonlarca dolar harcamakta, ancak bu sitelerin çoğu kuruluşun hedeflerine ulaşmasında yeterli olmamaktadır. Araştırmalarda, bu yetersizliğin nedeninin, başarısız internet sitesi tasarımları olduğu belirtilmektedir (Hausman ve Siekpe, 2009, s. 5). Bu açıdan önemli bir rol üstlenen internet sitesi tasarımının pazarlama literatüründe genel olarak çevrimiçi işletmecilik bakımından kritik bir konu olduğu söylenebilmektedir.

Karimov, Brengman ve Van Hove'e (2011, s.274) göre pazarlama literatüründe internet site tasarımı bileşenleri, görsel tasarım, sosyal işaret tasarımı ve içerik tasarımı olmak üzere üç boyutta sınıflandırılmıştır. İnternet sitesi görsel tasarımı, tüketicilere ilk izlenimi veren grafik ve yapısal faktörler olarak tanımlanmaktadır. İnternet site sosyal tasarımı, farklı iletişim medyaları aracılığıyla internet arayüzüne yerleştirilmiş yüz yüze etkileşim ve sosyal varlık gibi işaretleri içermektedir. Son olarak, internet site içerik tasarımı ise, internet sitesinin bilgilendirici metin veya grafik bileşenlerinden oluşmaktadır. Ganguly, Dash, Cyr ve Head (2010, s.305) çalışmasında, internet site tasarımını bilgi tasarımı, navigasyon tasarımı ve grafik tasarım olmak üzere üç boyuta ayırmıştır. Bilgi tasarımı, bir ürünü anlatan doğru veya yanlış bilgilerin internet sitesi kullanıcısına ileten internet sitesi öğelerini kapsarken grafik tasarımı denge, duygusal çekicilik, estetik ve tekdüzelik oluşturmada önem arz eden renkler, fotoğraflar, şekiller veya yazı tipi gibi unsurları içermektedir. Navigasyon tasarımı ise, kullanıcıların internet sitesinin farklı bölümlerine erişmelerine yardımcı olmak veya engel olmak için kullanılan gezinme şemasını ifade etmektedir (Cyr, 2008).

Geçmişte internet sitesi tasarımı ile, güven (örneğin, Ou ve Sia, 2010; Lowry, Wilson ve Haig (2014), memnuniyet (örneğin, Shergill ve Chen, 2005; Bai, Law ve Wen, 2008) ve satın alma niyeti (örneğin, Ganguly, Dash ve Cyr, 2009; Yanık, 2017) değişkenleri arasındaki ilişkiler incelenmiştir. Bu çalışmanın amacı da çevrimiçi alışverişte internet sitesi tasarımı faktörlerinin, müşteri güven, müşteri 
memnuniyeti ve satın alma niyetine etkisini araştırmaktır. $\mathrm{Bu}$ doğrultuda, gerçekleştirilen literatür taraması sonrası bir saha araştırmasıyla veriler elde edilmiş ve araştırma değişkenleri arasındaki ilişkiler önerilen bir model ile incelenmiştir.

\section{Teorik Çerçeve}

\section{1. İnternet Site Tasarımının Müşteri Güvenine Etkisi}

Tüketicilerin belirli bir çevrimiçi satıcıdan alışveriş yapma niyetini etkileyen ve sonuçta gerçek satın alma davranışına yol açan unsurlardan biri çevrimiçi güvendir (Ou ve Sia, 2010, s. 915). Sosyal ve ekonomik birçok etkileşimde önemli bir unsur olduğu bilinen güven (Gefen, 2000, s. 726), bir tarafın (alıcının) başka bir tarafa (satıcıya) yönelik beklentilerine göre belirsizlikle karakterize edilen öznel değerlendirmesi olarak tanımlanabilmektedir (Segovia, Jennex ve Beatty, 2009, s. 38). Pazarlama alanında güven, tüketicilerin belirli özellikler hakkındaki algılarından türetilen inançlar olarak tanımlanmakta olup, bu özellikler marka, mal veya hizmet, satış görevlilerini ve mal veya hizmetlerin satın alındığı ve satıldığı kuruluşu içermektedir (Flavián, Guinalíu ve Gurrea, 2006, s. 2).

Geleneksel mağazalardan gerçekleştirilen alışverişte müşteriler, güven konusundaki risk algıları, sanal mağazalardan yapılan alışverişlere kıyasla daha düşük olabilmektedir. Çünkü geleneksel mağazalarda hem ürün kalitesi kontrol edilerek ürün satın alınabilmekte, hem de ürünün ödemesi nakit yapılmaktadır. Diğer yandan, sanal mağazalardan yapılan alışverişte ürünün kalitesinden, kişisel bilgileri veya kredi kartı bilgilerinin paylaşılmasına kadar bazı endişeler duyulabilmekte, bu durum ise çevrimiçi müşterilerin çevrimiçi mağazaya yönelik güven duygularını olumsuz yönde etkileyerek bu mağazalardan satın almamalarına neden olabilmektedir (Grabner-Krauter ve Kaluscha, 2003, s. 784).

Yapılan araştırmalarda, müşterilerin, çevrimiçi alışverişte güven elde etmede internet sitesi tasarımı ile ilgili unsurları keşfetmeye yönelik eğilimleri olduğu sonucuna ulaşılmıştır. Örneğin, Cyr (2008) ve Yoon (2002) çalışmalarında, internet sitesi tasarımının çeşitli faktörlerinin B2C e-ticaret bağlamında nasıl güven oluşturduklarına dair ampirik kanıtlar sağlamaya çalışmışlardır. Ou ve Sia (2010) çalışmasında, internet sitesi tasarımının özelliklerinin, müşteri güven ve güvensizliğine anlamlı etkisinin olduğunu ortaya çıkarmışlardır.

İnternet site tasarımının bileşenleri hakkında yapılan araştırmalar incelendiğinde, grafik tasarım bileşeninin çerçevesine ait internet sitesi tasarımında renk çekiciliğini araştıran Cyr, Head ve Larios (2010), internet sitesi renk çekiciliğinin (colour appeal), müşterilerin bir işletmenin internet sitesine yönelik güveni üzerinde önemli bir etkiye sahip olduğu sonucuna ulaşmışlardır. Ayrıca, Pengnate ve Sarathy (2017), internet sitesinin algılanan görsel çekiciliğinin müşteri güveni üzerinde güçlü bir etki yarattığını bulmuşlardır. İnternet sitesinin sosyal 
tasarımına konusunda araştırmalar yapan Hassanein, Head ve Ju (2009) ise müşterilere kendilerinin diğer insanların tecrübelerinden faydalanmalarını hissettiren ve internet sitesinde gezinirken sicaklık yaratan unsurların (sosyal açıdan zengin resimler ve metinler, kişisel selamlar, akıllı ajanlar, vb.) bulunmasının müşteri güveni üzerinde olumlu yönde etkisi olduğu sonucuna ulaşmışlardır. Aslında, bu sosyal unsurlar (internet sitesinde yer alan metinler ve resimler) internet sitesinin bilgi tasarımı ve görsel tasarımı unsurlarını oluşturmaktadır.

Li ve Yeh (2010) çalışmalarının sonucunda, internet site tasarım unsurları (renkler, şekiller, dil, müzik, animasyon, resimler, dekoratif yazı tipi ve renkli butonlar), yararlılığı ve kullanım kolaylığının artırılmasında ve internet sitesinin özelleştirilmesi bağlamında internet tasarım unsurları ile müşterinin mobil ticaret internet sitesine yönelik güveni artırdığı sonucuna varmışlardır. İşletmelerin kurumsal kimliğin oluşturulması sürecinde de internet site tasarımının önemli rol oynadığ 1 bilinmektedir (Bulut, 2011, s. 145). Ha ve Im'e (2011, s. 81) göre yazı tipi rengi, arka plan rengi, animasyonlu görüntüler ve etkileşim özellikleri gibi internet sitesi tasarım unsurları, online alışveriş yapanların hissettikleri duygu veya ruh hallerini olumlu yönde etkilemektedir. İnternette sunulan bilgi yapısının ve grafik kalitesinin kullanıcı deneyimi üzerinde önemli bir etkisi olmaktadır (Cyr ve Bonanni, 2005, s. 568). Ayrıca, Lowry vd. (2014) yaptıkları çalışmada, firmanın internet sitesinde kullandığ 1 logosunun internet sitesine giriş yapan müşterinin güveni sağlamada ilk etkiyi sağladığı ve internet site tasarımı özelliklerinin (tutarlılık, istikrarlı şekiller, çağdaşlık ve rahatlatan renkler) müşteri güvenini olumlu bir şekilde etkilemekte olduğunu belirtmişlerdir. Kullanıcıların bir internet sitesinin farklı bölümlerine erişmelerine yardımcı olmak veya onları engellemek için kullanılan navigasyon tasarımının da (Cyr, 2008, s. 54), müşteri güvenini olumlu yönde etkilediği bilinmektedir (Ijaz ve Rhee, 2018). Ayrıca Ganguly vd. (2009), e-ticaret internet sitesinin grafikler, renkler ve fotoğraflar gibi görsel tasarım yönlerinin çevrimiçi mağazaya olan güveni olumlu etkilediğini deneysel olarak desteklemiştir. Bu açıklamalardan yola çıkılarak bu araştırmada internet site tasarımı faktörlerinin güveni etkilediğine yönelik olarak şu hipotezler geliştirilmiştir:

H1a: E-ticaret internet sitesi bilgi tasarımının, müşterinin e-ticaret işletmesine yönelik güven üzerinde olumlu etkisi vardır.

H1b: E-ticaret internet sitesi navigasyon tasarımının, müşterinin e-ticaret işletmesine yönelik güven üzerinde olumlu etkisi vardır.

H1c: E-ticaret internet sitesi grafik tasarımının, müşterinin e-ticaret işletmesine yönelik güven üzerinde olumlu etkisi vardır.

\section{2. İnternet Site Tasarımının Müşteri Memnuniyetine Etkisi}


Oliver (1980) müşteri memnuniyetini, müşterilerin bir mal veya hizmetin ihtiyaçları ve beklentileri açısından değerlendirmeleri olarak tanımlamıştır. Çevrimiçi perakendecilik literatüründe müşteri memnuniyeti, firmanın ilişki programlarının merkezindedir (Kim, Jin ve Swinney, 2009, s. 241). Bearden ve Teel'e (1983) göre de memnuniyet, kıt kaynakların harcanmalarının ve/veya daha önce karşılanmamış ihtiyaçların karşılanmasının olumlu bir sonucunu yansıtmaktadır. Genel anlamda memnuniyet, tüketici ilişkisini oluşturan tüm unsurların değerlendirilmesinden kaynaklanan duygusal bir tüketici tavrı olarak tanımlanabilir (Flavián vd., 2006, s.4). Benzer şekilde, geleneksel bakış açısıyla yapılan araştırmalarda memnuniyet, alıcının satıcıyla ilişkisini oluşturan tüm yönlerin bütünsel olarak değerlendirilmesinden oluşan duygusal bir tavrı olarak tanımlanmış ve memnuniyet müşterilerin bir mal veya hizmeti yeniden satın alma ve yeniden kullanma niyetlerinin önemli bir öncül değişkeni olduğu belirtilmiştir (Belanche, Casaló ve Guinalíu, 2012, s. 124).

Memnuniyet, Oliver (1997) tarafından, müşterilerin alışveriş deneyimlerinde zevkli bir tatmin algısı olarak tanımlanmıştır. Psikolojik olarak da memnuniyet, tüketicinin bir deneyiminden beklentileri çevreleyen duygusunun, o deneyim hakkındaki önceki duygularıyla birleştiğinde ortaya çıkan özet psikolojik bir durumudur (Hsu, Chang ve Chen, 2012, s. 554). Bir internet sitesinden memnuniyet ise, internet sitesinin çekiciliği ile ziyaretçileri başka bir siteye geçmek yerine internet sitesinde kalmaya teşvik eden tüm internet sitesi özelliklerinin toplamı ile ilişkilidir (Cyr ve Bonanni, 2005, s. 568; Cyr vd., 2010, s. 5).

Fung ve Lee (1999), internet sitesinde yer alan mevcut bilginin kalitesinin kullanıcının şirkete bakış açısını doğrudan etkilediğini ve daha çekici ve kullanıcı dostu bir internet site arayüz tasarımının, kullanıcıların memnuniyetini daha da hızlı ve kolay sağladığını belirtmişlerdir. Flavián vd. (2006) tarafından gerçekleştirilen çalışmada, müşterinin çevrimiçi alışveriş internet sitesine yönelik algıladığı kullanılabilirliğin, navigasyon tasarımı bağlamında memnuniyeti ve güveni etkilemede oynadığı rol üzerine yaptıkları çalışmada internet sitesinde kullanılabilirlik, sitede gezinmenin algılanan kolaylığını yansıttığını ve bunun ise müşteri güveninin artırılmasında önemli bir unsur olduğunu belirtmişlerdir.

Bai vd. (2008) internet sitesi kalitesinin seyahat internet sitelerini ziyaret eden kişilerin memnuniyeti üzerine etkisini araştırdıkları çalışmada, internet site kalitesini işlevsellik ve kullanılabilirlik bakımında iki boyutta değerlendirmişlerdir. Araştırmaya göre işlevsellik içeriğe işaret etmekteyken, kullanılabilirlik tasarım yönünü açıklamaktadır. Bai vd.'nin (2008) araştırma sonuçları, dil, düzen ve grafikler ile ölçülen kullanılabilirliğin, memnuniyet üzerinde işlevselliğe kıyasla daha fazla etkiye sahip olduğu bulunmuştur.

İşletmelerin internet sitesinin ana sayfa sunumu müşteri memnuniyetinin önemli bir belirleyicisi olup (Shergill ve Chen, 2005, s. 82), internet sitesi tasarım1, kalite, 
memnuniyet ve müşteri sadakati ile ilgili müşteri kararlarını güçlü bir şekilde etkilemektedir (Wolfinbarger ve Gilly, 2003, s. 183). Alam ve Yasin (2010, s. 73), çevrimiçi alışverişte internet sitesi tasarımı ile çevrimiçi alışveriş memnuniyeti arasında anlamlı pozitif yönde bir ilişkinin olduğu sonucuna ulaşmışlardır. Dolayısıyla, bu araştırmada internet site tasarımı faktörlerinin müşteri memnuniyetini etkilediğine yönelik olarak şu hipotezler geliştirilmiştir:

H2a: E-ticaret internet sitesi bilgi tasarımının, müşterinin e-ticaret işletmesinden memnuniyet üzerine olumlu etkisi vardır.

H2b: E-ticaret internet sitesi navigasyon tasarımının, müşterinin e-ticaret işletmesinden memnuniyet üzerine olumlu etkisi vardır.

H2c: E-ticaret internet sitesi grafik tasarımının, müşterinin e-ticaret işletmesinden memnuniyet üzerine olumlu etkisi vardır.

\section{3. İnternet Site Tasarımının Müşteri Satın Alma Niyetine Etkisi}

Müşterilerin satın alma niyetlerini anlamak, gerçek davranışlarını tahmin etmede kullanılmasindan dolayı önem arz etmektedir (Bai vd., 2008, s. 394). Sam ve Tahir (2009, s. 20) ise satın alma niyetini, tüketicinin ürünü satın alma olasılığ olarak tanımlamıştır. Benzer şekilde Hong ve Cha (2013, s.933), çevrimiçi satın alma niyetini, tüketicinin çevrimiçi satın alma eğilimi olarak tanımlamıştır. Satın alma niyeti, tüketicilerin internet sitesi kalitesi, bilgi kalitesi ve ürün algilanan kalitesi ile ilgili yapmış olduğu değerlendirmelerin sonucunu ifade etmekte ve gerçek satın alma davranışının önemli bir öngörücüsü olduğu belirtilmektedir (Chen, Hsu ve Lin, 2010, s.1008). E-ticarette müşterinin satın alma niyeti, bir internet sitesinden mal veya hizmet satın alma olasılığ ile ilgilidir (Ganguly vd., 2010, s. 307).

Bir internet site tasarımı, müşterilerin çevrimiçi satın alma kararını etkilemekte (Shergill ve Chen, 2005, s. 82) ve müşteri ilişkileri oluşturma, müşteri desteğini kolaylaştırma ve ziyaretçileri çevrimiçi ortamda gerçek müşterilere dönüştürmede kritik bir rol oynamaktadır (Hausman ve Siekpe, 2009, s. 11). Internet sitesi tasarımı özellikleri, hem müşteri güvenini etkileme yoluyla dolaylı, hem de doğrudan bir şekilde müşteri satın alma niyeti üzerinde etkiye sahip olduğu bilinmektedir (Ganguly vd., 2009; Ou ve Sia, 2010).

İnternet sitesinin sadece bilgisayarlarda kullanılabilmesine uygun olarak tasarlanmış olması durumunda, bu internet sitesinin farklı bir cihazda (örneğin akıllı telefon) açıldığ 1 durumlarda yazılar ve görseller istenen şekilde görülemeyecek ve kullanıcılar memnuniyetsizlik yaşayarak o internet sitesinden hemen çıkış yapmasına neden olabilecektir. Örneğin, Aytekin (2019) çalışmasında, duyarlı internet sitesi tasarımının ve tabletlerin ekran boyutunun üniversite öğrencilerinin tabletlerde okuduklarını anlama, bilişsel yüklenme ve 
okuma tercihleri üzerindeki etkilerini incelemiştir. Bu kapsamda Ankara'da bir üniversitenin lisans öğrencilerine anket uygulamış ve duyarlı internet sitesi tasarımının tabletlerde okuma tercihi üzerinde önemli bir etkisi olduğu sonucuna ulaşılmıştır. Yanık (2017) ise, seyahat sektöründe internet tasarımının ve internet bağlılığının çevrimiçi satın alma niyetine etkisini, Dubai'de dokuz otelden toplanan 367 çevrimiçi anket verisi ile incelemiştir. Araştırma sonuçlarına göre, internet site tasarım kalitesinin yüksek olduğu durumda, müşterilerin internet sitesinden memnuniyeti ve nihayetinde satın alma niyeti olumlu yönde etkilendiği sonucu elde edilmiştir (Yanık, 2017, s. 79).

Bai vd. (2008, s.398) tarafindan yapılan çalışma sonucuna göre seyahat internet sitesi grafik ve içerik kalitesi internet sitelerini ziyaret eden kişilerin memnuniyetini etkileyerek satın alma niyetini etkilemektedir. Kuo, Wu ve Deng (2009) tarafından yapılan çalışmada içerik kalitesi müşteri memnuniyetini etkileyerek satın alma niyeti üzerine olumlu etkiye sahip olduğu sonucuna varmışlardır. Aynı yönde, Zhou, Lu ve Wang'ın (2009) çalışmasına göre internet sitesi tasarımı kalitesi ve hizmet kalitesinin müşterilerin güven ve memnuniyeti üzerinde önemli ölçüde etkisi olduğunu ve bunun her ikisinin de geri satın alma niyetine yol açtığını göstermektedir.

Wells, Valacich ve Hess (2011) araştırmalarında, internet site kalitesinin ürünün kalitesine ve tüketici satın alma niyetine etkisini incelemiş ve araştırma sonucunda internet site kalitesinin tüketicilerin ürün kalitesine yönelik algılamalarını etkileyerek, satın alma niyetleri üzerine etkisi olduğu sonucuna varmışlardır. Literatürde yer alan bu çalışmalardan yola çıkılarak internet site tasarımı faktörlerinin satın alma niyetine etkisine yönelik olarak şu hipotezler geliştirilmiştir:

H3a: E-ticaret internet sitesi bilgi tasarımının, müşterinin e-ticaret işletmesinden satın alma niyeti üzerine olumlu etkisi vardır.

H3b: E-ticaret internet sitesi navigasyon tasarımının, müşterinin e-ticaret işletmesinden satın alma niyeti üzerine olumlu etkisi vardır.

H3c: E-ticaret internet sitesi grafik tasarımının, müşterinin e-ticaret işletmesinden satın alma niyeti üzerine olumlu etkisi vardır.

Araştırmacılar, internet site tasarımının müşteri güven, memnuniyet ve satın alma niyeti üzerine etkisini farklı örneklemler üzerinde incelenmişlerdir. Örneğin, Tran ve $\mathrm{Vu}$ (2019) elektronik hizmet işletmelerinde müşteri güveninin, memnuniyet ve satın alma niyetini etkilediğini ortaya koymuştur. Bai, Law ve Wen (2008), gerçekleştirdikleri araştırma sonucunda, memnuniyetin satın alma niyetleri üzerinde doğrudan ve olumlu bir etkisi olduğunu bulmuşlardır. Bu araştırmada da müşterilere yönelik internet site tasarımının müşteri güven, memnuniyet ve satın alma niyetini etkileyip etkilemediğinin yanı sıra, müşteri güven, memnuniyet ve 
satın alma niyeti arasındaki etkileri test etmek amacıyla ayrıca şu hipotezler geliştirilmiştir:

H4: Müşterinin e-ticaret işletmesine yönelik güvenin, e-ticaret işletmesinden memnuniyet üzerinde olumlu etkisi vardır.

H5: Müşterinin e-ticaret işletmesine yönelik güvenin, e-ticaret işletmesinden satın alma niyeti üzerine olumlu etkisi vardır.

H6: Müşterinin e-ticaret işletmesinden memnuniyetinin, e-ticaret işletmesinden satın alma niyeti üzerinde olumlu etkisi vardır.

\section{Araştırmanın Yöntemi}

Elektronik ticaretin hızlı gelişmesiyle ve insanların çoğunda çevrimiçi alışverişe yöneldikten sonra, artık insanlar fiziksel mağazadan satın almalarıla birlikte bir internet sitesi üzerinde büyük bir oranda alışveriş yapmaktadır. Bu durumda, müş̧terilerin tutumlarının internet sitesinin özellikleri ve tasarımından etkilendiği düşünülmektedir. $\mathrm{Bu}$ bağlamda araştırmanın amacı, e-ticaret işletmelerinin internet site tasarımının çevrimiçi alışveriş yapan tüketicilerin internetten satın alma sürecinde güven, memnuniyet ve sipariş tamamlama niyeti üzerine etkilerini incelemektir.

Araştırmanın amacı doğrultusunda, Bursa ilinde öğrenim görmekte olan üniversite öğrencilerinden oluşan evren içerisinden çevrimiçi alışveriş yapan üniversite öğrencileri (çalışmanın örneklemi) üzerine uygulanan anketler yoluyla veriler elde edilmiştir. Araştırmanın katılımcılarından e-ticaret internet sitelerinin arasından en çok alışveriş yaptı̆̆ çevrimiçi mağazayı belirtmeleri istenmiş ve belirttikleri internet sitesi ile ilgili olarak bu çalışmanın belirlenen değişkenlerinin incelenmesine çalışılmıştır.

\subsection{Evren ve Örneklem}

$\mathrm{Bu}$ araştırmanın evreni, Bursa ilinde 2018-2019 yllında eğitim gören 75002 üniversite öğrencisinden (YÖK, 2019) oluşmaktadır. Araştırma evreninin öğrencilerden oluşmasının nedeni, üniversite öğrencilerinin ürünleri çevrimiçi inceleme ve/veya satın alma süreçlerinde deneyimlerinin yeterli düzeyde olmaları ve daha yaşlı bireylere kıyasla interneti kullanma eğilimlerinin daha fazla olmalarıdır (Sam ve Tahir, 2009, s. 22). Ayrıca, literatürde internet tasarımının tüketicilerin satın alma davranışlarına etkisini inceleyen birçok araştırmacı da, çalışmalarının örneklemlerini öğrencilerden oluşturmuşlardır (Örneğin, Hassanein ve Head, 2007; Wu, Lee, Fu ve Wang 2014; Sam ve Tahir, 2009; Wells vd., 2011; Kuan, Bock ve Vathanophas, 2008; Aytekin, 2019). Bu çalışmada, evrendeki tüm bireylere ulaşılması mümkün olamadığından örnekleme yapılması uygun 
görülmüş ve 2019 yılı Ocak-Mart ayları arasında amaçlı örnekleme yöntemi (sadece çevrimiçi alışveriş yapan öğrenciler) ile araştırmanın verileri toplanmıştır.

\subsection{Araştırmanın Modeli}

$\mathrm{Bu}$ çalışmada, e-ticaret internet sitesi bilgi tasarımı, e-ticaret internet sitesi navigasyon tasarımı, e-ticaret internet sitesi grafik tasarımı, müşterinin e-ticaret işletmesine yönelik güven, memnuniyet ve satın alma niyeti olmak üzere altı değişken bulunmaktadır. Araştırma değişkenlerine ait model ve araştırma hipotezleri, Şekil 1'de görülmektedir.

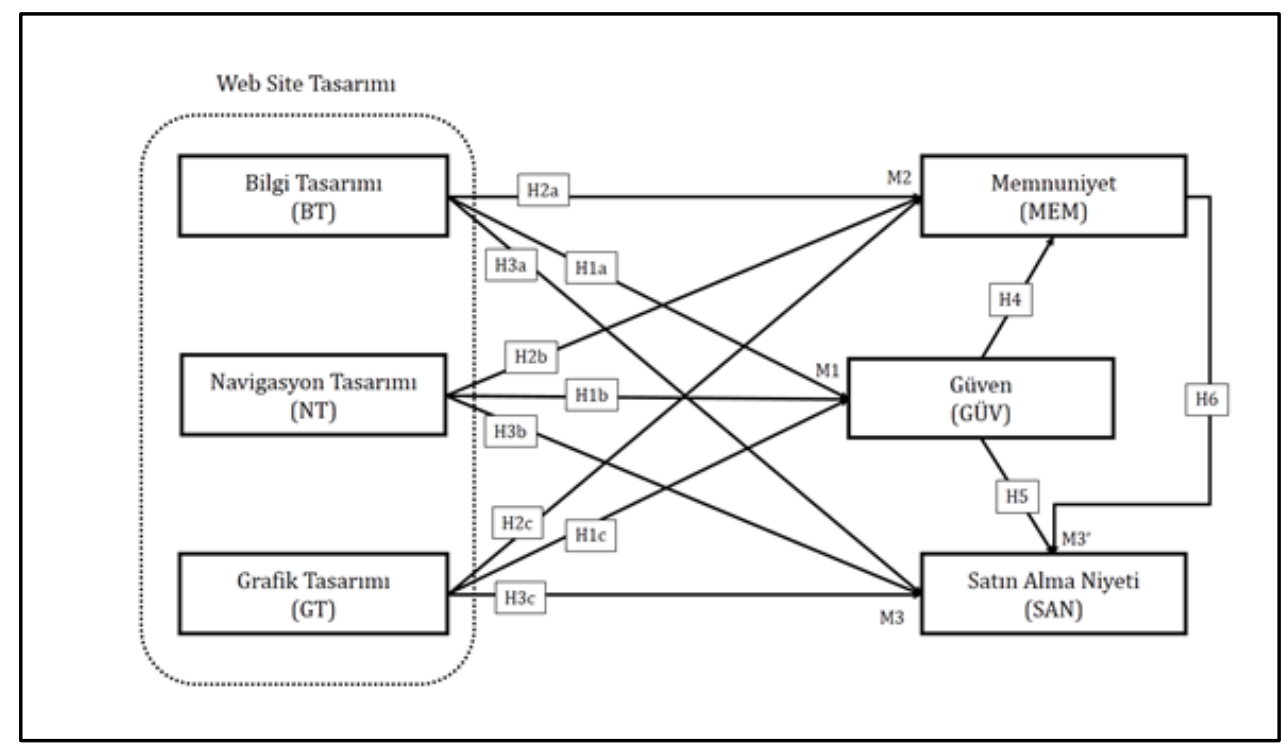

Şekil 1. Araştırma Modeli

Araştırmada alt boyutları bilgi tasarımı, grafik tasarımı ve navigasyon tasarımı olan internet sitesi tasarımı ile güven değişkenlerini ölçmek amacıyla Ganguly vd. (2010) tarafından kullanılan ölçeklerden yararlanılmıştır. Memnuniyeti ölçmede Flavián vd.'nin (2006), satın alma niyetini ölçmede ise Lee ve Lin'in (2005) çalışmalarında kullandıkları ölçeklerden yararlanılmıştır. Araştırmada kullanılan ölçek ifadelerinin tümü 1="kesinlikle katılmıyorum", 2="katılmıyorum", 3="ne kat1liyorum ne kat1lmiyorum", 4="katıliyorum", 5="kesinlikle kat1liyorum" olacak şekilde 5'li Likert derecelendirme tipinde değerlendirilmiştir. Bu araştırmanın ölçeklerinin, güvenilirlikleri ve geçerlilikleri alındıkları çalışmalarda gerçekleştirilmiştir. Diğer yandan bu çalışmada da, araştırmada yer alan değişkenlerin geçerliliği ve güvenilirliği sınanmıştır. Değişkenlerin geçerliliğini test etmek amacıyla doğrulayıcı faktör analizi, güvenilirliğini test etmede ise Cronbach's alpha yöntemi kullanılmıştır. Bu çalışmanın değişkenleri arasında eş (çoklu) doğrusallığın sorun olmadığını belirlemede ve hipotezleri test etmede çoklu doğrusal regresyon analizinin kademeli yöntemi (Stepwise Method) 
kullanılmıştır. $\mathrm{Bu}$ araştırmanın analizlerini gerçekleştirmek amacıyla istatistiksel paket programlar kullanılmıştır.

\section{Bulgular}

\subsection{Araştırmanın Örnekleminin Özellikleri}

Bu bölümde araştırmaya katılan kişilerin bazı demografik özellikleri ile ilgili bulgular yer almaktadır. Katılımcıların cinsiyet, yaş, öğrenim durumu, iş ve aylık net geliri gibi örneklem özellikleri Tablo 3'te gösterilmektedir. Araştırmaya katılan 441 bireyden, 4'ü yaşını, 1'i öğrenim durumu ve 3'ü ise aylık hanehalkı gelirini belirtmek istememiştir.

Tablo 3: Örneklem Özellikleri

\begin{tabular}{|l|l|l|}
\hline \multicolumn{2}{|l|}{ n } & $\%$ \\
\hline Cinsiyet & 278 & 63,0 \\
\hline Erkek & 163 & 37,0 \\
\hline Kadın & \multicolumn{2}{l|}{} \\
\hline Yaş & 322 & 73,0 \\
\hline $18-24$ & 102 & 23,1 \\
\hline $25-31$ & 11 & 2,5 \\
\hline $32-38$ & 2 & 0,5 \\
\hline $39-45$ & \multicolumn{2}{|l|}{} \\
\hline Öğrenim Durumu & 22 & 5,0 \\
\hline Lise & 35 & 7,9 \\
\hline Yüksek Okul & 322 & 73,0 \\
\hline Lisans & 55 & 12,5 \\
\hline Yüksek Lisans & 6 & 1,4 \\
\hline Doktora & \multicolumn{2}{|l|}{} \\
\hline Aylık Hanehalkı Net Geliri (TL) & 104 & 23,6 \\
\hline $0-1000$ & 95 & 21,5 \\
\hline $1001-2000$ & 76 & 17,2 \\
\hline $2001-3000$ & 66 & 15,0 \\
\hline $3001-4000$ & 97 & 22,0 \\
\hline $4001+$ & \multicolumn{2}{|l|}{} \\
\hline
\end{tabular}

Örnekleminin öğrencilerden oluştuğu bu çalışmanın demografik özelliklerine dair frekans dağılımları Tablo 3'ten incelendiğinde, katılımcıların \%63'ünün erkek ve \%37'sinin kadın, \%73'ünün lisans öğrencisi ve çoğunluğunun yaşının 18-24 aralığında olduğu görülmektedir.

\subsection{Geçerlilik ve Güvenilirlik Analizleri}

Araştırmada kullanılan ölçeklerin gerekçelendirilerek, test yorumlamasının doğrulanması veya yapı geçerliliğinin oluşturulması için ayrışma geçerliliğinin ve yakınsak geçerliliğin sağlanması gerekmektedir (Campbell ve Fiske, 1959, s. 81). $\mathrm{Bu}$ çalışmada kullanılan ölçeklerin geçerliliğinin değerlendirilmesi için doğrulayıcı faktör analizi kullanılmıştır. Doğrulayıcı faktör analizi (DFA) 
yönteminin uygulanmasında Ganguly vd.'nin (2010) çalışmasından yararlanılmıştır. $\mathrm{Bu}$ ampirik çalışmada elde edilen verilere doğrulayıcı faktör analizi yapmak için SPSS AMOS programı kullanılmış, ve doğrulayıcı faktör analizi sonucunda CMIN/DF $=2,842 \leq 3(\mathrm{p}=0,000<0,001), \mathrm{CFI}=0,926 \geq 0,9$, IFI $=0,927 \geq 0,9$ ve RMSEA $=0,065 \leq 0,08$ değerleri elde edilmiştir. DFA sonucu hesaplanan iyilik endeksleri, ölçeklerin iyi bir uyuma sahip olduğunu göstermektedir (Ganguly vd., 2010, s.314).

Tablo 1: Araştırmanın Ölçek İfadelerine Dair DFA Sonucu

\begin{tabular}{|c|c|c|c|c|c|}
\hline Değişken & İfade & $\begin{array}{l}\text { Faktör } \\
\text { Yükü }\end{array}$ & AVE & CR & $\begin{array}{l}\text { Cronbach's } \\
\text { Alpha }\end{array}$ \\
\hline \multirow{2}{*}{$\begin{array}{l}\text { BT - Bilgi Tasarımı } \\
\text { ( } 2 \text { ifade) }\end{array}$} & BT1 & 0,677 & \multirow{2}{*}{0,51} & \multirow{2}{*}{0,67} & \multirow{2}{*}{0,669} \\
\hline & BT2 & 0,747 & & & \\
\hline \multirow{2}{*}{$\begin{array}{l}\text { GT - Grafik Tasarımı } \\
\text { ( } 2 \text { ifade) }\end{array}$} & GT1 & 0,758 & \multirow{2}{*}{0,56} & \multirow{2}{*}{0,72} & \multirow{2}{*}{0,714} \\
\hline & GT2 & 0,734 & & & \\
\hline \multirow{3}{*}{$\begin{array}{l}\text { NT - Navigasiyon } \\
\text { Tasarımı } \\
\text { (3 ifade) }\end{array}$} & NT1 & 0,762 & \multirow{3}{*}{0,53} & \multirow{3}{*}{0,77} & \multirow{3}{*}{0,759} \\
\hline & NT2 & 0,784 & & & \\
\hline & NT3 & 0,627 & & & \\
\hline \multirow{7}{*}{$\begin{array}{l}\text { GÜV - Güven } \\
\text { (7 ifade) }\end{array}$} & GÜV1 & 0,803 & \multirow{7}{*}{0,45} & \multirow{7}{*}{0,85} & \multirow{7}{*}{0,841} \\
\hline & GÜV2 & 0,773 & & & \\
\hline & GÜV3 & 0,463 & & & \\
\hline & GÜV4 & 0,526 & & & \\
\hline & GÜV5 & 0,684 & & & \\
\hline & GÜV6 & 0,622 & & & \\
\hline & GÜV7 & 0,731 & & & \\
\hline \multirow{4}{*}{$\begin{array}{l}\text { MEM - Memnuniyet } \\
\text { (4 ifade) }\end{array}$} & MEM1 & 0,836 & \multirow{4}{*}{0,60} & \multirow{4}{*}{0,85} & \multirow{4}{*}{0,850} \\
\hline & MEM2 & 0,827 & & & \\
\hline & MEM3 & 0,725 & & & \\
\hline & MEM4 & 0,687 & & & \\
\hline \multirow{2}{*}{$\begin{array}{l}\text { SAN - Satın Alma Niyeti } \\
\text { ( } 2 \text { ifade) }\end{array}$} & SAN1 & 0,715 & \multirow{2}{*}{0,60} & \multirow{2}{*}{0,75} & \multirow{2}{*}{0,742} \\
\hline & SAN2 & 0,825 & & & \\
\hline
\end{tabular}

Fornell ve Larcker'a (1981) göre, yakınsama geçerliliğinin ihtiyatlı bir tahminleyicisi olarak, hesaplanan ortalama varyansin (AVE) 0,5 değerinden yüksek olması gerektiğini belirtmiştir. Diğer yandan, eğer AVE 0,5'ten küçük ve bileşik güvenilirliği (CR) 0,6 değerinden yüksekse, yapının yakınsak geçerliliğinin hala yeterli düzeyde olduğu bilinmektedir (Fornell ve Larcker, 1981, s.46). Bu doğrultuda, Tablo 1'de görüldüğü gibi araştırmada kullanılan ölçeklerin yakınsama geçerliliklerinin kabul edildiği söylenebilir.

Ayrışma geçerliliği, farklı değişkenlerin birbirinden ayrışma düzeyini göstermekte olup, ayrışma geçerliliğinin sağlanabilmesi için, değişkenlerin diğer değişkenlerle arasındaki ilişkinin düşük olması gerekmektedir. Bu doğrultuda, bir ölçeğin ortalama açıklanan varyans (AVE) değerinin karekökü, ilgili ölçeğin araştırmada 
incelenen diğer ölçeklerle arasındaki korelasyon katsayısı değerlerinden büyük olmas1 gerekmektedir (Fornell ve Larcker, 1981, s.46). Tablo 2'de değişkenler arası ilişkiler ve hesaplanan açıklanan ortalama varyansın karekök değerlerine bakıldığında, araştırmanın her bir ölçeği için ortalama açıklanan varyansın karekök değerinin, ilgili ölçeğin diğer ölçeklerle arasındaki korelasyon katsayısı değerlerinden büyük olduğu görülmektedir. Dolayısıyla, araştırmada kullanılan ölçeklerin ayrışım geçerliliğini de sağladığı sonucuna ulaşılabilmektedir.

Tablo 2: Değişkenler Arası İlişkiler ve Hesaplanan Ortalama Açıklanan Varyansın Karekök Değerleri

\begin{tabular}{|l|c|c|c|c|c|c|}
\cline { 2 - 7 } \multicolumn{1}{c|}{} & BT & GT & NT & GÜV & MEM & SAN \\
\hline BT & $\mathbf{0 , 7 1 4}$ & & & & & \\
\hline GT & $0,523^{* *}$ & $\mathbf{0 , 7 4 8}$ & & & & \\
\hline NT & $0,494^{* *}$ & $0,554^{* *}$ & $\mathbf{0 , 7 2 8}$ & & & \\
\hline GÜV & $0,428^{* *}$ & $0,375^{* *}$ & $0,424^{* *}$ & $\mathbf{0 , 6 7 1}$ & & \\
\hline MEM & $0,385^{* *}$ & $0,404^{* *}$ & $0,396^{* *}$ & $0,661^{* *}$ & $\mathbf{0 , 7 7 4}$ & \\
\hline SAN & $0,381^{* *}$ & $0,319^{* *}$ & $0,321^{* *}$ & $0,582^{* *}$ & $0,633^{* *}$ & $\mathbf{0 , 7 7 4}$ \\
\hline$* *$ p $<0.01$
\end{tabular}

$\mathrm{Bu}$ çalışmada kullanılan ölçeklerin güvenilirliklerini belirlemede Cronbach alfa katsayılarından faydalanılmıştır. Bu çalışmanın ölçeklerinin Cronbach alfa katsayıları Tablo 1'de görülmekte olup sırasıyla, $\mathrm{Alfa}(\mathrm{BT})=0,669 ; \mathrm{Alfa}(\mathrm{GT})=$ 0,714; $\mathrm{Alfa}(\mathrm{NT})=0,759 ; \mathrm{Alfa}(\mathrm{GÜV})=0,841 ; \mathrm{Alfa}(\mathrm{MEM})=0,850 ; \mathrm{Alfa}(\mathrm{SAN})=$ 0,742 şeklindedir. $\mathrm{Bu}$ sonuçlara göre, güven ve memnuniyet ölçeklerinin güvenilirliği iyi düzeyde olup, grafik tasarımı, navigasyon tasarımı ve satın alma niyeti ölçeklerinin güvenilirliğinin ise kabul edilebilir düzeydedir. Ayrıca, bilgi tasarımı ölçeğinin Cronbach Alfa katsayısı değerine bakıldığında $(0,669)$, güvenilirliğinin yeterli düzeyde olduğu söylenebilmektedir.

\subsection{Araştırma Hipotezlerinin Test Edilmesi}

$\mathrm{Bu}$ çalışmanın hipotezlerini test etmede çoklu doğrusal regresyon analizinin (Multiple Linear Regression Analysis) kademeli yöntemi (stepwise method) kullanılmıştır. $\mathrm{Bu}$ doğrultuda, Ganguly vd.'nin (2010) çalışmalarında uyguladıkları yöntem uyarlanmıştır. Çoklu regresyon yönteminin kullanılabilmesi için açıklayıcı değişkenlerin arasında eş (çoklu) doğrusal bağlantılar (kolerasyon) tam veya güçlü (yüksek) olmamalı ve verilerin dağılımı normal dağılım olmalıdır (Williams, Grajales ve Kurkiewicz, 2013; Rashidi, Ranjitkar ve Hadas, 2014). Bu doğrultuda, öncelikle çalışma modelinde açıklayıcı değişkenlerin arasındaki eş (çoklu) doğrusallık değerlendirilmiştir. Ayrıca, açıklayıcı değişkenlerin VIF (Variance inflation factor) değerinin 10'dan küçük ve tolerans değerinin 0,1 'den büyük olduğunda açıklayıcı değişkenler arasında eş (çoklu) doğrusallığın sorun 
olmadığı bilinmektedir (Mansfield ve Helms, 1982, s.160; Uyanık ve Güler, 2013, s.238).

Tablo 4: Regresyon Analizinde Açılayıcı Değişkenlerin Tolerans ve VIF Değerleri

\begin{tabular}{|l|l|l|}
\hline Açıklayıcı Değişken & Tolerans & VIF \\
\hline BT - Bilgi Tasarımı & 0,667 & 1,499 \\
\hline GT - Grafik Tasarımı & 0,611 & 1,637 \\
\hline NG - Navigasyon Tasarımı & 0,635 & 1,574 \\
\hline GÜV - Güven & 0,563 & 1,775 \\
\hline MEM - Memnuniyet & 0,563 & 1,775 \\
\hline
\end{tabular}

Tablo 4 incelendiğinde, bu çalışmanın açıklayıcı değişkenlerinin VIF değerlerinin kabul edilen değerin (10) altında ve tolerans değerlerinin ise kabul edilen değerden $(0,1)$ büyük olduğu görülmektedir. Dolayısıyla, açıklayıcı değişkenler arasında çoklu doğrusal ilişki bulunmadığı söylenebilmektedir. Bu bağlamda bu çalışmanın ölçekleri, çoklu regresyon yönteminin kullanılabilmesinin ilk şartını sağlamaktadır. Çalışmanın verilerine çoklu regresyon yönteminin uygulanabilmesinin ikinci şartı olan verilerinin normal dağılım gösterip göstermediğinin test edilmesi amacıyla, her bir değişken için normal Q-Q çizimi çıkarılmıştır (Williams vd., 2013; Das ve Imon, 2016). Q-Q çiziminde dikey eksen düz çizgiyle beklenen normal dağılımını temsil ederken yatay eksen noktalarla kayıt edilen verilerin dağılımını temsil etmektedir. Araştırmanın verilerinin Q-Q çizimi yapılmış ve noktaların doğrusal çizgiye oldukça yakın veya çizginin etrafında kümelendiği gözlemlenmiştir. Bu durum istatistiksel dağılıma yönelik varsayımın makul olduğunu ve dolayısıyla verilerin normal dağılım sergilediğini göstermektedir. Sonuç olarak, bu çalışmanın verileri çoklu regresyon yönteminin kullanılabilmesinin ikinci şartı da gerçekleştirilmiş olup, bu çalışmanın hipotezlerinin çoklu regresyon yöntemi ile test edilmesi uygun bulunmuştur.

\subsection{1. İnternet Site Tasarımı Faktörlerinin Müşteri Güveni Üzerindeki Etkisinin Test Edilmesi}

İstatistiksel paket programını kullanarak çoklu doğrusal regresyon analizine GÜV bağımlı değişken olarak ve BT, NT ve GT açıklayıcı değişken olarak girilmiş ve internet site bilgi (BT), navigasyon (NT) ve grafik (GT) tasarım faktörlerinin müşteri güvenini etkileyip etkilemediği incelenmeye çalışılmıştır.

Tablo 5'te görüldüğü gibi ANOVA testinde, $(\mathrm{F}=48,753, \mathrm{p}<0,001)$ olması, $\mathrm{BT}$, NT ve GT açıklayıcı değişkenlerin, bağımlı değişken olan güven üzerinde istatistiksel olarak anlamlı etkilerin bulunduğunu göstermektedir. Durbin-Watson testi değeri, 1,5-2,5 civarında olduğunda otokorelasyon olmadığı bilinmektedir (Kalaycı, 
2010). Çoklu doğrusal regresyon analizi sonuçları incelendiğinde, Durbin-Watson değerinden (1,783), analizde otokorelasyon olmadığı söylenebilmektedir.

Tablo 5: İnternet Site Tasarımının Güven Üzerine Etkisi ${ }^{a}$

\begin{tabular}{|c|c|c|c|c|c|}
\hline $\begin{array}{l}\text { Bağımsız } \\
\text { Değiş̧kenler }\end{array}$ & $\begin{array}{c}\text { Standardize } \\
\text { Edilmemiş } \\
\beta\end{array}$ & $\begin{array}{c}\text { Standardize } \\
\beta\end{array}$ & $\begin{array}{l}\text { Standart } \\
\text { Hata }\end{array}$ & $\begin{array}{c}\mathrm{t}- \\
\text { istatistiği }\end{array}$ & p-değeri \\
\hline Sabit değişken & 1,325 & - & 0,183 & 7,259 & 0,000 \\
\hline $\begin{array}{l}\text { BT - Bilgi } \\
\text { Tasarımı }\end{array}$ & 0,239 & 0,253 & 0,048 & 5,000 & 0,013 \\
\hline $\begin{array}{l}\text { NT - Navigasyon } \\
\text { Tasarımı }\end{array}$ & 0,238 & 0,238 & 0,052 & 4,580 & 0,000 \\
\hline $\begin{array}{l}\text { GT - Grafik } \\
\text { Tasarımı }\end{array}$ & 0,094 & 0,110 & 0,045 & 2,080 & 0,038 \\
\hline \multicolumn{6}{|c|}{$\begin{array}{l}\text { Bağımlı değişken: GÜV (Güven) } \\
R=0,501, \quad R^{2}=0,251, \quad R_{\text {düzeltilmis }}^{2}=0,246, \\
\text { Durbin-Watson değeri=1,783 }\end{array}$} \\
\hline
\end{tabular}

Regresyon analizi sonucuna göre, açıklayıcı değişkenler (BT, NT ve GT), bağımlı değişken (GÜV) varyansının \% 25,1'ini açıklamaktadır. Her ne kadar $\mathrm{R}^{2}$ değeri düşük olsa da, sosyal bilimlerde, regresyon analizi sonucunda $\mathrm{R}^{2}$ değerinin düşük olduğu durumlarla sıklıkla karşılaşılmakta ve regresyon analizinin amacının yüksek $\mathrm{R}^{2}$ değeri elde etmekten çok, regresyon katsayılarıyla ilgili güvenilir tahminler elde etmek ve istatistiksel çıkarımlarda bulunmak olduğu bilinmektedir (Atılgan, 2012, s. 99). Tablo 5'e bakıldığında, analiz sonuçları, internet site bilgi tasarımının (BT), müşteri güvenini (GÜV) istatistiksel olarak anlamlı ve pozitif yönde etkilediğini göstermektedir $(\beta=0,253, \mathrm{t}>2, \mathrm{p}<0,001)$, dolayısıyla H1a desteklenmiştir. Aynı şekilde, müşteri güveninin (GÜV) internet site navigasyon tasarımı (NT) tarafindan $(\beta=0,238, \mathrm{t}>2, \mathrm{p}<0,001)$ ve internet site grafik tasarımı (GT) tarafindan $(\beta=0,110, \mathrm{t}>2, \mathrm{p}<0,05)$ istatistiksel olarak anlamlı ve pozitif yönde etkilendiği söylenebilmektedir. Sonuç olarak $\mathrm{H} 1 \mathrm{a}, \mathrm{H} 1 \mathrm{~b}$ ve $\mathrm{H} 1 \mathrm{c}$ desteklenmiştir.

\subsection{2. İnternet Site Tasarımı Faktörlerinin Müşteri Memnuniyeti Üzerindeki Etkisinin Test Edilmesi}

$\mathrm{Bu}$ bölümde, internet site bilgi (BT), navigasyon (NT) ve grafik (GT) tasarım faktörlerinin müşteri memnuniyetini etkileyip etkilemediğini incelenmeye çalışılmıştır. MEM bağımlı değişken olarak ve BT, NT ve GT açıklayıcı değişken olarak analize dahil edilmiştir.

Tablo 6'da Durbin-Watson test değerinden $(1,855)$, analizde otokorelasyon olmadığı söylenebilmektedir. Tablo 6'ya bakıldığında, internet site bilgi tasarımının (BT) $(\beta=0,185, \mathrm{t}>2, \mathrm{p}<0,001)$, internet site navigasyon tasarımının 
(NT) $(\beta=0,194, \mathrm{t}>2, \mathrm{p}<0,001)$ ve internet site grafik tasarımının (GT) $(\beta=0,200, \mathrm{t}$ $>2, \mathrm{p}<0,001)$ müşteri memnuniyeti (MEM) üzerinde pozitif yönde istatistiksel olarak anlamlı etkisinin olduğu görülmektedir. Bu nedenle, $\mathrm{H} 2 \mathrm{a}, \mathrm{H} 2 \mathrm{~b}$ ve $\mathrm{H} 2 \mathrm{c}$ hipotezleri desteklenmiştir.

Tablo 6: İnternet Site Tasarımının Memnuniyet Üzerine Etkisi ${ }^{a}$

\begin{tabular}{|c|c|c|c|c|c|}
\hline $\begin{array}{l}\text { Bağımsız } \\
\text { Değiş̧kenler }\end{array}$ & $\begin{array}{l}\text { Standardize } \\
\text { Edilmemiş } \beta\end{array}$ & $\begin{array}{c}\text { Standardize } \\
\beta\end{array}$ & $\begin{array}{c}\text { Standart } \\
\text { Hata }\end{array}$ & $\begin{array}{c}\mathrm{t}- \\
\text { istatistiği }\end{array}$ & p-değeri \\
\hline Sabit değişken & 1,856 & - & 0,182 & 10,170 & 0,000 \\
\hline $\begin{array}{l}\text { BT - Bilgi } \\
\text { Tasarımı }\end{array}$ & 0,172 & 0,185 & 0,048 & 3,600 & 0,000 \\
\hline $\begin{array}{l}\text { NT - Navigasyon } \\
\text { Tasarımı }\end{array}$ & 0,191 & 0,194 & 0,052 & 3,675 & 0,000 \\
\hline $\begin{array}{l}\text { GT - Grafik } \\
\text { Tasarımı }\end{array}$ & 0,168 & 0,200 & 0,045 & 3,713 & 0,000 \\
\hline \multicolumn{6}{|c|}{$\begin{array}{l}\text { Bağımlı değişken: MEM (Memnuniyet) } \\
R=0,478, \quad R^{2}=0,229, \quad R_{\text {düzeltilmis }}^{2}=0,223, \\
\text { Durbin-Watson test değeri }=1,855\end{array}$} \\
\hline
\end{tabular}

\subsection{3. İnternet Site Tasarımı Faktörlerinin Müşteri Satın Alma Niyeti Üzerindeki} Etkisinin Test Edilmesi

$\mathrm{Bu}$ bölümde, internet sitesinin bilgi tasarım (BT), navigasyon tasarım (NT) ve grafik tasarım (GT) faktörlerinin müşteri satın alma niyetini etkileyip etkilemediği incelenmiştir. Bu doğrultuda SAN bağımlı değişken olarak ve BT, NT ve GT açıklayıcı değişken olarak ele alınarak, çoklu regresyon analizinin kademeli yöntemi uygulanmıştır.

\section{Tablo 7: İnternet Site Tasarımı Faktörlerinin Satın Alma Niyeti Üzerine} Etkisi $^{a}$

\begin{tabular}{|lccccc|}
\hline $\begin{array}{l}\text { Bağımsız } \\
\text { Değişkenler }\end{array}$ & $\begin{array}{c}\text { Standardize } \\
\text { Edilmemiş } \boldsymbol{\beta}\end{array}$ & $\begin{array}{c}\text { Standardize } \\
\boldsymbol{\beta}\end{array}$ & $\begin{array}{c}\text { Standart } \\
\text { Hata }\end{array}$ & $\begin{array}{c}\text { t- } \\
\text { istatistiği }\end{array}$ & p-değeri \\
\hline Sabit değişken & 1,413 & - & 0,245 & 5,760 & 0,000 \\
\hline $\begin{array}{l}\text { BT - Bilgi } \\
\begin{array}{l}\text { Tasarımı } \\
\text { NT - Navigasyon }\end{array}\end{array}$ & 0,312 & 0,258 & 0,064 & 4,856 & 0,000 \\
$\begin{array}{l}\text { Tasarımı } \\
\text { GT - Grafik } \\
\text { Tasarımı }\end{array}$ & 0,170 & 0,133 & 0,070 & 2,434 & 0,015 \\
\hline $\begin{array}{l}\text { Bağımlı değişken: SAN (Satın Alma Niyeti) } \\
R=0,420, \quad R^{2}=0,176, \quad R_{\text {düzeltilmiş }}^{2}=0,170,\end{array}$ & $F=31,129$ & \\
$\begin{array}{l}R \\
\text { Durbin Watson test değeri=1,904 }\end{array}$ & 0,110 & 0,061 & 1,982 & \\
\hline
\end{tabular}


Çoklu doğrusal regresyon analizi sonuçları Tablo 7'de incelendiğinde, DurbinWatson test değerinden (1,904), analizde otokorelasyon olmadığ söylenebilmektedir. Tablo 7 incelendiğinde, internet site bilgi tasarımının (BT) $(\beta=0,285, \mathrm{t}>2, \mathrm{p}<0,001)$, internet site navigasyon tasarımının (NT) $(\beta=0,133, \mathrm{t}$ $>2, \mathrm{p}<0,05)$ ve internet site grafik tasarımının $(\mathrm{GT})(\beta=0,110, \mathrm{t} \rightarrow 2, \mathrm{p}<0,05)$ müşteri satın alma niyeti üzerine (SAN) pozitif yönde istatistiksel olarak anlamlı etkisi olduğu görülmektedir. Böylece, $\mathrm{H} 3 \mathrm{a}, \mathrm{H} 3 \mathrm{~b}$ ve $\mathrm{H} 3 \mathrm{c}$ hipotezleri desteklenmiştir.

\subsection{4. İnternet Site Tasarımı Faktörlerinin Müssteri Güven ve Memnuniyetini} Etkileyerek Satın Alma Niyeti ile İlişkilerinin Test Edilmesi

Lee ve Lin'in (2005) çalışmasına benzer şekilde, H1a, H1b, H1c, H2a, H2b ve H2c desteklendikten sonra internet site tasarımı faktörlerinin (BT, NT ve GT) güveni ve memnuniyeti etkileyerek satın alma niyeti üzerine etkisinin olup olmadığı sorgulanmıştır.

Tablo 8'de görüldüğü gibi, Durbin-Watson test değerinden $(1,913)$, analizde otokorelasyon olmadığı görülmektedir. Çoklu regresyon analizi sonuçları, güvenin (GÜV) $(\beta=0,661, t<2, p>0,001)$, müşteri memnuniyeti üzerinde pozitif yönde istatistiksel olarak anlamlı bir etkisi vardır. Dolayısıyla H4 hipotezi desteklenmiştir.

Tablo 8: Müşteri Güveninin Müşteri Memnuniyeti Üzerine Etkisia

\begin{tabular}{|c|c|c|c|c|c|}
\hline $\begin{array}{l}\text { Bağımsız } \\
\text { Değisşkenler }\end{array}$ & $\begin{array}{l}\text { Standardize } \\
\text { Edilmemis } \beta\end{array}$ & $\begin{array}{c}\text { Standardize } \\
\beta\end{array}$ & $\begin{array}{l}\text { Standart } \\
\text { Hata }\end{array}$ & $\begin{array}{c}\mathbf{t}- \\
\text { istatistiği }\end{array}$ & p-değeri \\
\hline Sabit değişken & 1,598 & - & 0,126 & 12,713 & 0,000 \\
\hline GÜV - Güven & 0,651 & 0,661 & 0,035 & 4,856 & 0,000 \\
\hline \multicolumn{6}{|c|}{$\begin{array}{l}\text { Bağımlı değişken: MEM (Memnuniyet) } \\
R=0,661, \quad R^{2}=0,437, \quad R_{\text {düzeltilmiş }}^{2}=0,435, \\
\text { Durbin Watson test değeri }=1,913\end{array}$} \\
\hline
\end{tabular}

Son olarak, SAN bağımlı değişken, GÜV ve MEM ise açıklayıcı değişken olmak üzere çoklu regresyon analizinin kademeli yöntemi uygulanmıştır. Tablo 9 incelendiğinde, Durbin-Watson test değerinden $(1,922)$, analizde otokorelasyon olmadı ̆̆ 1 görülmekte ve güven (GÜV) $(\beta=0,290, \mathrm{t}>2, \mathrm{p}<0,001)$ ile memnuniyetin (MEM) $(\beta=0,441, t>2, p<0,001)$ müşteri satın alma niyetini (SAN) pozitif yönde istatistiksel olarak anlamlı düzeyde etkilediği görülmektedir.

Sonuç olarak, H5 ve H6 hipotezleri desteklenmiştir. Lee ve Lin (2005) tarafından gerçekleştirilen çalışmaya benzer şekilde, internet site tasarımı faktörlerinin güveni ve memnuniyeti pozitif yönde etkilediği ve güven ve memnuniyetin de satın alma niyetini pozitif yönde etkilediği sonucu ortaya çıkmıştır. Dolayısıyla, 
internet site tasarımı faktörlerinin satın alma niyeti üzerinde de pozitif yönde dolaylı etkisi bulunmaktadır.

\section{Tablo 9: Müşteri Güveni ve Müşteri Memnuniyetinin Satın Alma Niyeti Üzerine Etkisi ${ }^{a}$}

\begin{tabular}{|c|c|c|c|c|c|}
\hline $\begin{array}{l}\text { Bağımsız } \\
\text { Değiş̧kenler }\end{array}$ & $\begin{array}{l}\text { Standardize } \\
\text { Edilmemiş } \beta\end{array}$ & $\begin{array}{c}\text { Standardize } \\
\beta\end{array}$ & $\begin{array}{l}\text { Standart } \\
\text { Hata }\end{array}$ & $\begin{array}{c}\mathbf{t}- \\
\text { istatistiği }\end{array}$ & p-değeri \\
\hline Sabit değişken & 1,161 & - & 0,190 & 0,849 & 0,396 \\
\hline GÜV - Güven & 0,372 & 0,290 & 0,061 & 6,140 & 0,000 \\
\hline $\begin{array}{l}\text { MEM - } \\
\text { Memnuniyet }\end{array}$ & 0,574 & 0,441 & 0,062 & 9,337 & 0,000 \\
\hline \multicolumn{6}{|c|}{$\begin{array}{l}\text { Bağımlı değişken: SAN (Satın Alma Niyeti) } \\
R=0,670, \quad R^{2}=0,448, \quad R_{\text {düzeltilmis }}^{2}=0,446, \\
\text { Durbin Watson test değeri= } 1,922\end{array}$} \\
\hline
\end{tabular}

\section{Sonuç}

Günümüzde özellikle Covid-19 pandemisinin etkisiyle tüketicilerin çevrimiçi alışverişe daha fazla eğilim göstermesi ve gelişen internet teknolojisiyle birlikte satıcıları müşterileriyle dijital pazarda buluşturan birçok e-ticaret işletmeleri, tüketicilerin alışveriş davranışlarında önemli bir yer edinmiştir. Güçlü rekabete sahip ve müşteri odaklı bu dijital pazarda, internet sitesi, çevrimiçi satıcılar ve müşterileri arasındaki ana ve tek arayüzü temsil etmektedir. Bunun için bu arayüzün çevrimiçi müşterilerin tutum ve kararlarına etkilerini incelemenin önemli olduğu görülmüştür. Bu çalışmanın sonuçlarında da görüldüğü gibi, geleneksel mağazalardan farklı olarak, internet perakendecilerinin satışlarını gerçekleştirdikleri e-ticaret internet sitelerinin bilgi tasarımı, navigasyon tasarımı ve grafik tasarımı, müşterinin e-ticaret işletmesine yönelik tüketicilerin güven, memnuniyet ve satın alma niyetlerini etkileyen unsurlar olarak karşımıza çıkmaktadır. Ayrıca bu çalışmada, güven, hem memnuniyet hem de satın alma niyetlerinin önemli bir öngörücüsü olduğu sonucuna ulaşılmıştır. Bu sonuçların, daha önce gerçekleştirilen araştırmaları destekler nitelikte olduğunu söylemek mümkündür (örneğin, Bai vd., 2008; Ganguly vd., 2009; Ou ve Sia, 2010).

$\mathrm{Bu}$ çalışmadan elde edilen bulgular değerlendirildiğinde, e-ticaret internet sitelerinde yer alacak bilgilerin etkili (doğru, açık ve güvenilir) bir şekilde yer almasının, tüketici güveni ve nihayetinde satın alma davranışı üzerinde anlamlı etkisi olacağı düşünülmektedir. Ayrıca, e-ticaret işletmelerinin, müşterileriyle etkileşim sağlayabilecekleri ve böylece müşterilerin soru ve yorumlarına yanıt vererek müşterileri memnun edebilecekleri internet site tasarımlarıyla satış başarılarını da sağlayacaklardır. İşletmeler, başarılı bir şekilde oluşturulmuş internet sitesi içerikleri yoluyla tüketicilerin çevrimiçi satın alma deneyimlerini olumlu yönde etkileyebilecektir. Özellikle insan davranışının özelliklerinin dikkate alındığı, yenilikçi, interaktif ve satın alma risklerinin en düşük düzeye 
indirgendiği internet site tasarımlarıyla yoğun rekabetin daha da arttığı elektronik perakendecilikte rekabette önemli bir avantaj elde edilecektir.

Özellikle dünyada toplumların çevrimiçi alışverişe eğilimlerinin daha da artacağı ve işletmelerin internet sitelerinin tasarımları ile ilgili konuların pazarlama alanında daha fazla dikkat çekeceği düşünülmektedir. Gelecekte bu alanda yapılacak olan çalışmaların farklı tüketici grupları üzerinde ve farklı değişkenler kullanılarak gerçekleştirilmesiyle bu çalışmanın genellenebilmesi mümkün olabilecektir. Örneğin gelecekte yapılacak olan çalışmalarda, işletmelerin internet sitesi tasarımlarının işletme itibarına, marka denkliğine veya kalite algılarına etkilerinin de dahil edilmesiyle, işletmelerin kurumsal yapısına dair çıkarımlar sağlanabilecektir. Ayrıca sektörel anlamda internet sitesi tasarımının farklılıklarının yanı sıra, mobil çevrimiçi alışveriş yapılabilecek farklı elektronik cihazlar (bilgisayar, akıllı telefon, tablet gibi) açısından oluşabilecek farklılıkların incelenmesi önerilebilir. Bu bağlamda gelecekte internet sitesi tasarımının farklı boyutlarının da dahil edildiği ve sektörler arası farklılıkları da dikkate alan daha kapsamlı ölçeklerin geliştirilmesine de ihtiyaç duyulmaktadır.

\section{Kaynakça}

Alaimo, L. S., Fiore, M. ve Galati, A. (2020). How the Covid-19 pandemic is changing online food shopping human behaviour in Italy. Sustainability, 12(22), 9594.

Alam, S. S. ve Yasin, N. M. (2010). An investigation into the antecedents of customer satisfaction of online shopping. Journal of Marketing Development and Competitiveness, 5(1), 71-78.

Atılgan, K. Ö. (2012). Marka denkliğini oluşturan boyutların referans fiyat oluşumuna etkisinin hafif ticari araç markaları üzerinde incelenmesi. Yayınlanmamış Doktora Tezi. Çukurova Üniversitesi, Adana.

Aytekin, M. (2019). The effects of responsive website design and screen size of tablets on university students' reading comprehension, cognitive load, and preference of reading on tablets. Yayınlanmamış Yüksek Lisans Tezi. Orta Doğu Teknik Üniversitesi, Ankara.

Bai, B., Law, R. ve Wen, I. (2008). The impact of website quality on customer satisfaction and purchase intentions: evidence from Chinese online visitors. International Journal of Hospitality Management, 27(3), 391-402.

Baltac1, A. ve Akaydın, H. (2020). COVID-19 Pandemi sürecinin tüketicilerin gıda ürünlerini satın alma davranışları üzerindeki etkisi: bir literatür taraması. Yüksek İhtisas Üniversitesi Să̆llk Bilimleri Dergisi, 1, 57-64. 
Bearden, W. O. ve Teel, J. E. (1983). Selected determinants of consumer satisfaction and complaint reports. Journal of Marketing Research, 20(1), 21-28.

Belanche, D., Casaló, L. V. ve Guinalíu, M. (2012). Website usability, consumer satisfaction and the intention to use a website: the moderating effect of perceived risk. Journal of Retailing and Consumer Services, 19(1), 124132.

Bulut, T. (2011). Kurumsal kimliğin yaratım sürecinde web sitesi tasarımı. Yayınlanmamış Doktora Tezi. Haliç Üniversitesi, İstanbul.

Campbell, D. T. ve Fiske, D. W. (1959). Convergent and discriminant validation by the multitrait-multimethod matrix. Psychological Bulletin, 56(2), 81105.

Chen, Y. H., Hsu, I. C. ve Lin, C. C. (2010). Website attributes that increase consumer purchase intention: a conjoint analysis. Journal of Business Research, 63(9-10), 1007-1014.

Cyr, D. (2008). Modeling web site design across cultures: relationships to trust, satisfaction, and e-loyalty. Journal of Management Information Systems, 24(4), 47-72.

Cyr, D. ve Bonanni, C. (2005). Gender and website design in e-business. International Journal of Electronic Business, 3(6), 565-582.

Cyr, D., Head, M. ve Larios, H. (2010). Colour appeal in website design within and across cultures: a multi-method evaluation. International Journal of Human-Computer Studies, 68(1-2), 1-21.

Das, K. R. ve Imon, A. H. M. R. (2016). A brief review of tests for normality. American Journal of Theoretical and Applied Statistics, 5(1), 512 .

Flavián, C., Guinalíu, M. ve Gurrea, R. (2006). The role played by perceived usability, satisfaction and consumer trust on website loyalty. Information \& Management, 43(1), 1-14.

Fornell, C. ve Larcker, D. F. (1981). Evaluating structural equation models with unobservable variables and measurement error. Journal of Marketing Research, 18(1), 39-50.

Fung, R. ve Lee, M. (1999). EC-trust (trust in electronic commerce): exploring the antecedent factors. AMCIS 1999 Proceedings, 179, 517-519. 
Ganguly, B., Dash, S. B. ve Cyr, D. (2009). Website characteristics, trust and purchase intention in online stores:-an empirical study in the Indian context. Journal of Information Science \& Technology, 6(2), 24-44.

Ganguly, B., Dash, S. B., Cyr, D. ve Head, M. (2010). The effects of website design on purchase intention in online shopping: the mediating role of trust and the moderating role of culture. International Journal of Electronic Business, 8(4-5), 302-330.

Gefen, D. (2000). E-commerce: the role of familiarity and trust. Omega, 28(6), 725-737.

Grabner-Kräuter, S. ve Kaluscha, E. A. (2003). Empirical research in on-line trust: a review and critical assessment. International Journal of HumanComputer Studies, 58(6), 783-812.

Ha, Y. ve Im, H. (2012). Role of web site design quality in satisfaction and word of mouth generation. Journal of Service Management, 23(1), 79-96.

Hassanein, K. ve Head, M. (2007). Manipulating perceived social presence through the web interface and its impact on attitude towards online shopping. International Journal of Human Computer Studies, 65(8), 689708.

Hassanein, K., Head, M. ve Ju, C. (2009). A cross-cultural comparison of the impact of social presence on website trust, usefulness and enjoyment. International Journal of Electronic Business, 7(6), 625-641.

Hausman, A. V. ve Siekpe, J. S. (2009). The effect of web interface features on consumer online purchase intentions. Journal of Business Research, 62(1), $5-13$

Hong, I. B. ve Cha, H. S. (2013). The mediating role of consumer trust in an online merchant in predicting purchase intention. International Journal of Information Management, 33(6), 927-939.

Hsu, C. L., Chang, K. C. ve Chen, M. C. (2012). The impact of website quality on customer satisfaction and purchase intention: perceived playfulness and perceived flow as mediators. Information Systems and e-Business Management, 10(4), 549-570.

Ijaz, M. F. ve Rhee, J. (2018). Constituents and consequences of online-shopping in sustainable e-business: An experimental study of online-shopping malls. Sustainability, 10(10), 3756. 
Kalayc1, Ş. (2010). SPSS uygulamalı çok değişkenli istatistik teknikleri. Beşinci Baskı, Ankara: Asil Yayın Dağıtım.

Karimov, F. P., Brengman, M. ve Van Hove, L. (2011). The effect of website design dimensions on initial trust: a synthesis of the empirical literature. Journal of Electronic Commerce Research, 12(4), 272-301.

Kim, J., Jin, B. ve Swinney, J. L. (2009). The role of etail quality, e-satisfaction and e-trust in online loyalty development process. Journal of Retailing and Consumer Services, 16(4), 239-247.

Kuan, H. H., Bock, G. W. ve Vathanophas, V. (2008). Comparing the effects of website quality on customer initial purchase and continued purchase at ecommerce websites. Behaviour \& Information Technology, 27(1), 3-16.

Kuo, Y. F., Wu, C. M. ve Deng, W. J. (2009). The relationships among service quality, perceived value, customer satisfaction, and post-purchase intention in mobile value-added services. Computers in Human Behavior, 25(4), 887-896.

Lee, G. G. ve Lin, H. F. (2005). Customer perceptions of e-service quality in online shopping. International Journal of Retail \& Distribution Management, 33(2), 161-176.

Li, Y. M., ve Yeh, Y. S. (2010). Increasing trust in mobile commerce through design aesthetics. Computers in Human Behavior, 26(4), 673-684.

Lowry, P. B., Wilson, D. W. ve Haig, W. L. (2014). A picture is worth a thousand words: source credibility theory applied to logo and website design for heightened credibility and consumer trust. International Journal of Human-Computer Interaction, 30(1), 63-93.

Mansfield, E. R. ve Helms, B. P. (1982). Detecting multicollinearity. The American Statistician, 36(3a), 158-160.

Oliver, R.L. (1980). A cognitive model of the antecedents and consequences of satisfaction decisions. Journal of Marketing Research, 17(4), 460-469.

Oliver, R.L. (1997). A behavioral perspective on the consumer. New York: Irwin/McGraw-Hill.

Ou, C. X. ve Sia, C. L. (2010). Consumer trust and distrust: an issue of website design. International Journal of Human-Computer Studies, 68(12), 913934. 
Pengnate, S. F. ve Sarathy, R. (2017). An experimental investigation of the influence of website emotional design features on trust in unfamiliar online vendors. Computers in Human Behavior, 67, 49-60.

Rashidi, S., Ranjitkar, P. ve Hadas, Y. (2014). Modeling bus dwell time with decision tree-based methods. Transportation Research Record, 2418(1), 74-83.

Sam, M., F. M. ve Tahir, M. N. H. (2009). Website quality and consumer online purchase intention of air ticket. International Journal of Basic \& Applied Sciences, 9(10), 4-9.

Segovia, R. H., Jennex, M. E. ve Beatty, J. (2009). Paralingual web design and trust in e-government. International Journal of Electronic Government Research, 5(1), 36-49.

Shergill, G. S. ve Chen, Z. (2005). Web-based shopping: consumers' attitudes towards online shopping in New Zealand. Journal of Electronic Commerce Research, 6(2), 79-94.

Tran, V. D. ve Vu, Q. H. (2019). Inspecting the relationship among E-service quality, E-trust, E-customer satisfaction and behavioral intentions of online shopping customers. Global Business \& Finance Review, 24(3), 29-42.

Uyanık, G. K. ve Güler, N. (2013). A study on multiple linear regression analysis. Procedia Social and Behavioral Sciences, 106(1), 234-240.

Wells, J. D., Valacich, J. S. ve Hess, T. J. (2011). What signal are you sending? how website quality influences perceptions of product quality and purchase intentions. MIS Quarterly, 35(2), 373-396.

Williams, M. N., Grajales, C. A. G. ve Kurkiewicz, D. (2013). Assumptions of multiple regression: correcting two misconceptions. Practical Assessment, Research, and Evaluation, 18(11), 1-14.

Wolfinbarger, M. ve Gilly, M. C. (2003). etailq: dimensionalizing, measuring and predicting etail quality. Journal of Retailing, 79(3), 183-198.

Wu, W. Y., Lee, C. L., Fu, C. S. ve Wang, H. C. (2014). How can online store layout design and atmosphere influence consumer shopping intention on a website?. International Journal of Retail \& Distribution Management, 42(1), 4-24.

Yanık, A. (2017). Otel web tasarımı ve web bağlılığının online satın alma niyetine etkisi: Dubai'deki iş gezginleri üzerine bir araştırma. International Review of Economics and Management, 5(3), 69-83. 
Yoon, S.J. (2002). The antecedents and consequences of trust in online-purchase decisions. Journal of Interactive Marketing, 16(2), 47-63.

YÖK (Yükseköğretim Kurulu). (2019). Yükseköğretim bilgi yönetim sistemi. (Erişim tarihi: 06 Ocak 2019), istatistik.yok.gov.tr

Zhou, T., Lu, Y. ve Wang, B. (2009). The relative importance of website design quality and service quality in determining consumers' online repurchase behavior. Information Systems Management, 26(4), 327-337. 


\section{The Effect of Website Design on Customer Trust, Customer Satisfaction, and Purchase Intention}

\section{Extended Abstract}

\section{Introduction}

Widespread use of internet access has led businesses to realize digital marketing strategies on the internet in order to gain a competitive advantage. On the other hand, as a result of the Covid-19 pandemic that emerged in 2019, it is known that consumers are more adapted to shopping from electronic retail channels and there is a significant increase in e-commerce volume in this sense (Alaimo, Fiore and Galati, 2020; Baltac1 and Akaydın , 2020). Businesses to be successful in this new competitive environment emerging with e-commerce depend on encouraging their customers to shop on their websites. The design of the websites of the businesses attracts the attention of researchers as well as business managers in the context of directing customers to online shopping. Ganguly, Dash, Cyr, and Head (2010, p.305) evaluated the website design into three dimensions: information design, navigation design, and graphic design. While information design includes website elements that convey true or false information about a product to the website user, the graphic design includes elements such as colors, photographs, shapes, or fonts that are important in creating balance, emotional appeal, aesthetics, and uniformity. Navigation design refers to the navigation scheme used to help or prevent users from accessing different parts of the website.

Previous studies on website design, trust (e.g. Ou \& Sia, 2010; Lowry, Wilson, \& Haig (2014), satisfaction (e.g. Shergill \& Chen, 2005; Bai, Law \& Wen, 2008), and purchase intention (e.g., Ganguly, Dash, \& Cyr, 2009; Yanık, 2017) variables were examined. This study aims to investigate the effect of website design factors on customer trust, customer satisfaction, and purchase intention in online shopping. The data were obtained and the relationships between research variables were examined with a proposed model.

\section{Methodology}

In order to achieve the study objective, the data were obtained through the questionnaires applied to university students from a population of university students studying in Bursa who shop online. Participants of the study were asked to indicate the online store where they shop the most among e-commerce websites, and it was tried to examine the variables determined in this study regarding the website they indicated.

In this context, 441 university students studying in the province of Bursa were reached with the purposive sampling method and the participants were asked to respond to statements about research variables through the questionnaires. In the study, the scales used by Ganguly et al. (2010) were used to measure the sub-dimensions of website design and trust. Also, the scales used by Flavián et al. (2006) in measuring satisfaction and by Lee and Lin (2005) in measuring the purchase intention were used. The collected data were analyzed by using the statistical package program and the research hypotheses were tested by using regression analysis.

\section{Results}

Analysis results show that website information design has a statistically significant and positive effect on customer trust. Similarly, it can be said that customer trust is statistically significant and positively affected by the website navigation design and the website graphic design. It is found 
that website information design, website navigation design, and website graphic design have a statistically significant positive effect on customer satisfaction. On the other hand, results show a statistically significant positive effect of website information design, website navigation design, and website graphic design on customer purchase intention. According to the regression results, trust has a statistically significant positive effect on customer satisfaction. Finally, it is found that trust and satisfaction have a statistically significant positive effect on customer purchase intention.

\section{Conclusion}

In the current highly competitive and customer-focused digital market environment, the website represents the main and only interface between online retailers and customers. For this reason, it is important to examine the effects of this interface on online customers' attitudes and decisions. From the results of this study, unlike traditional stores, the information design, navigation design, and graphic design of the e-commerce websites of online retailers are factors that affect the trust, satisfaction, and purchase intentions of the customers for the e-commerce business. In addition, in this study, it was concluded that trust is an important predictor of both satisfaction and purchase intentions. Therefore, it can be said that these results support the findings of previous studies (for example, Bai et al., 2008; Ganguly et al., 2009; Ou \& Sia, 2010).

It will be possible to generalize this study by carrying out future studies in this field on different consumer groups and using different variables. In addition, it may be suggested to examine the differences in the design of the website in the sectoral sense, as well as the differences that may occur in terms of different electronic devices (such as computers, smartphone, tablets) for online shopping. In this context, in the future, there is a need to develop more comprehensive scales that include different dimensions of website design and take into account the differences between sectors. 